\title{
The challenges of identifying partially digested human teeth : first description of Neandertal remains from the Mousterian site of Marillac (Marillac-le-Franc, Charente, France) and implications for palaeoanthropological research
}

Les challenges liés à l'identification de dents humaines partiellement digérées : première description de vestiges néandertaliens du site moustérien de Marillac (Marillac-le-Franc, Charente) et implications pour la recherche en paléoanthropologie.

Bruno Maureille, Sandrine Costamagno, Cédric Beauval, Alan E. Mann, María Dolores Garralda, Célimène Mussini, Véronique Laroulandie, William Rendu, Aurélien Royer, Guillaume Seguin and Bernard Vandermeersch

\section{(2) OpenEdition Journals}

Electronic version

URL: http://journals.openedition.org/paleo/3448

DOI: $10.4000 /$ paleo.3448

ISSN: $2101-0420$

Publisher

SAMRA

Printed version

Date of publication: 30 December 2017

Number of pages: 201-212

ISSN: $1145-3370$

Electronic reference

Bruno Maureille, Sandrine Costamagno, Cédric Beauval, Alan E. Mann, María Dolores Garralda, Célimène Mussini, Véronique Laroulandie, William Rendu, Aurélien Royer, Guillaume Seguin and Bernard Vandermeersch, « The challenges of identifying partially digested human teeth : first description of Neandertal remains from the Mousterian site of Marillac (Marillac-le-Franc, Charente, France) and implications for palaeoanthropological research », PALEO [Online], 28 | 2017, Online since 01 June 2018, connection on 07 July 2020. URL : http://journals.openedition.org/paleo/3448; DOI : https://doi.org/10.4000/paleo.3448

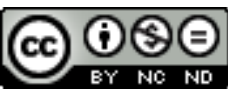

PALEO est mis à disposition selon les termes de la licence Creative Commons Attribution - Pas d'Utilisation Commerciale - Pas de Modification 4.0 International. 


\title{
The challenges of identifying partially digested human teeth: first description of Neandertal remains from the Mousterian site of Marillac (Marillac-le-Franc, Charente, France) and implications for palaeoanthropological research
}

\author{
Bruno MAUREILLE ${ }^{(a)}$, Sandrine COSTAMAGNO ${ }^{(b)}$, Cédric BEAUVAL ${ }^{\left({ }^{()}\right.}$, \\ Alan E. MANN( ${ }^{(\mathrm{d})}$, María Dolores GARRALDA ${ }^{(e)}$, Célimène MUSSINI(a), \\ Véronique LAROULANDIE ${ }^{(a)}$, William RENDU ${ }^{(a)}$, Aurélien ROYER ${ }^{(f, g)}$, \\ Guillaume SEGUIN( ${ }^{(\text {) }}$, Bernard VANDERMEERSCH(a)
}

Abstract: excavations at the collapsed cave site of Marillac (Marillac-le-Franc, Charente, France) ${ }^{1}$, uncovered in the lower half of the stratigraphy, a series of Late Pleistocene sedimentological facies containing a MIS 4/3 fauna. Also discovered were Middle Paleolithic artefacts (Quina Mousterian) and numerous fragmentary Neandertal fossils corresponding to a MNI of seven individuals.

Analyses of the geomorphology of the eastern locus of the site, of the artefacts and especially of the animal bones of the lower part of the stratigraphy, suggest that over the course of time the site was intermittently used by Neandertals for processing animal carcasses. Cave carnivores appear to have sometimes been involved in scavenging activities of the remains abandoned by humans.

Re-examination of two teeth - that were provisionally interpreted as bovid or cervid deciduous incisors by a palaeontologist unfamiliar with Pleistocene mammal fauna - have been identified as Neandertal maxillary permanent incisors. Originally considered as faunal deciduous incisors, what made their identification particularly difficult were the significant modifications to both the crown and roots of these teeth.

(a) Université de Bordeaux, CNRS, MCC, PACEA UMR5199, FR-33615 Pessac

(b) CNRS, Université Jean Jaurès Toulouse II, TRACES UMR5608, FR-31058 Toulouse cedex

(c) SARL Archéosphère, 2 rue des Noyers, FR-11500 Quirbajou

(d) Department of Anthropology, Princeton University, Princeton, NJ 08544, USA

(e) U. D. de Antropología Física. Facultad de Biología. Universidad Complutense de Madrid. E-28040 Madrid

(f) Université de Bourgogne, CNRS, Biogéosciences UMR6282, FR-21000 Dijon

(g) École Pratique des Hautes Études, Laboratoire EPHE PALEVO, FR-21000 Dijon

(h) Éveha Étude et valorisation archéologique, Route de Larnay, La Tardiverie, FR-86580 Biard

Corresponding authors:

*: bruno.maureille@u-bordeaux.fr

**: costamag@univ-tlse2.fr

(1) The original name for the site was Les Pradelles (David 1934), reflecting the name of the terrain where it is located. Later, during the 1965-1980 Vandermeersch excavations, the site was known as Marillac, the partial name of the village Marillac-le-Franc

(Vandermeersch 1965, 1971, 1976a and b). More recently, the name Les Pradelles has been employed during excavations between 2001 and 2013 (Maureille et al. 2004a, 2010). Both site names have been used in publications. 
This contribution explores the possible causes for this unusual morphology and, in particular, their ingestion by carnivores. This is the most parsimonious explanation as these teeth possess distinctive modifications clearly indicative of the effects of carnivore gastric secretion, damage which is described here for the first time for human teeth. Finally, a number of straight forward macroscopic features are described that permit the rapid identification of these specific taphonomic modifications on human teeth without the need for microscopy or micro-CT scanning. A literature review indicates that additional hominin teeth, with similar scavenger produced changes, may already have been identified at other sites, especially those dated to the Plio-Pleistocene.

Key-words: Taphonomy, incisor, carnivore, digestion, Quina Mousterian, France.

Résumé : Les challenges liés à l'identification de dents humaines partiellement digérées : première description de vestiges néandertaliens du site moustérien de Marillac (Marillac-le-Franc, Charente) et implications pour la recherche en paléoanthropologie. Les fouilles du gisement de Marillac (Marillac-le-Franc, Charente) ${ }^{1}$ ont autorisé l'identification d'un certain nombre de facies sédimentaires qui, pour la moitié inférieure de la stratigraphie, livrent une faune abondante rapportée au MIS 4/3. Du matériel lithique, bien plus rare, traduisant un techno-complexe moustérien de type Quina ainsi que de nombreux vestiges néandertaliens, correspondant à un NMI de sept individus, ont été mis au jour.

L'étude de l'évolution géomorphologique du locus « est » du site et l'étude du matériel lithique, des vestiges de faune de la moitié basale de la litho-stratigraphie plaident pour des activités de récupération par les Néandertaliens de toutes les ressources exploitables sur les cadavres ou les portions de cadavres de rennes. Ils s'y livrèrent par intermittence et de façon répétée. La fréquentation du gisement par des grands carnivores, qui ont ainsi pu charogner les restes abandonnés par les hommes, a été très sporadique.

Le réexamen des anciennes collections fauniques - précédemment étudiées par un paléontologue non familier avec les faunes du Pléistocène - a permis d'identifier deux dents (des incisives permanentes supérieures). Elles étaient considérées comme des incisives déciduales de bovidé ou de cervidé et sont en fait des incisives permanentes néandertaliennes. Ce qui avait rendu leur identification taxinomique difficile était leur morphologie générale aussi bien au niveau de la couronne que de la racine.

Cet article discute les causes potentielles qui pourraient expliquer ces modifications morphologiques de ces deux dents permanentes et en particulier celle de leur digestion partielle suite à leur ingestion par des carnivores. Cette cause est la plus parcimonieuse puisque ces deux incisives présentent des atteintes qui ne peuvent être que la conséquence de l'effet des attaques enzymatique et acide de l'estomac des carnivores. Nous décrivons donc pour la première fois ces dommages et ces modifications morphologiques sur des dents humaines. Enfin, cette contribution fournit aussi des clefs d'identification macroscopiques, simples et n'utilisant pas de techniques microscopiques, de micro CT-scans, qui permettent d'identifier rapidement ces modifications taphonomiques particulières sur des dents humaines. Ces clefs peuvent aider à trouver, comme nous avons pu le faire avec une revue bibliographique, au sein de collections de vestiges fauniques, de nouveaux fossiles humains du Plio-Pléistocène.

Mots-clés : taphonomie, incisive, carnivore, digestion Moustérien de type Quina, France.

\section{1 - Introduction}

Hominin remains are uncommon in the fossil and archaeological record; each find represents another piece of evidence in the reconstruction of extinct patterns of biology and behavior. Without the contribution of newly developed bio-chemical and paleogenetic techniques (Buckley and Collins 2011; Van Door et al. 2011; Welker et al. 2016), it is oftentimes difficult to recognize fragmentary hominin remains, especially small ones from long bone shafts, amongst a sample of animal bones. Teeth, with their distinctive morphology, are usually easily identified. This, however, is not always the case. Two teeth from the site of Marillac had been modified in such a way that their identification as human was extremely difficult.

Marillac is located in the village of Marillac-le-Franc, Department of the Charente, in the southwest of France, about $20 \mathrm{~km}$ east of Angoulême (fig. 1). The site is on the right bank of a very small stream, La Ligonne, a right tributary of the Tardoire River. Although casual activities at the site early in the last century had resulted in the discovery of a Neandertal mandibular fragment (David 1935; Piveteau 1957), systematic archaeological excavations at Marillac were not undertaken until 19651980 (Vandermeersch 1976a). More recent work at the site was carried out between 2001-2013 (Maureille et al. 2004a, 2010). Since the 1930s, 87 hominin fossils (corresponding to 109 field fragments), have been discovered, most of them cranial and dental remains plus a few post-cranial pieces. All these hominin specimens possess distinctive morphological attributes of Neandertals and many of them have been published or are available for the scientific community (Piveteau 1951, 1957; Vandermeersch 1976a, 1976b; Mann et al. 2002; Maureille et al. 2004a, 2004b; Mussini 2011; Mussini et al. 2011, 2012; Garralda et al. 2014a and b).

Re-examination of the 1965-1980 collection of faunal remains resulted in the discovery of a few hominin fragments, including two anterior teeth, from the same facies, which were previously identified as deciduous incisors of an herbivore, either a bovid or a cervid (fig. 2). 


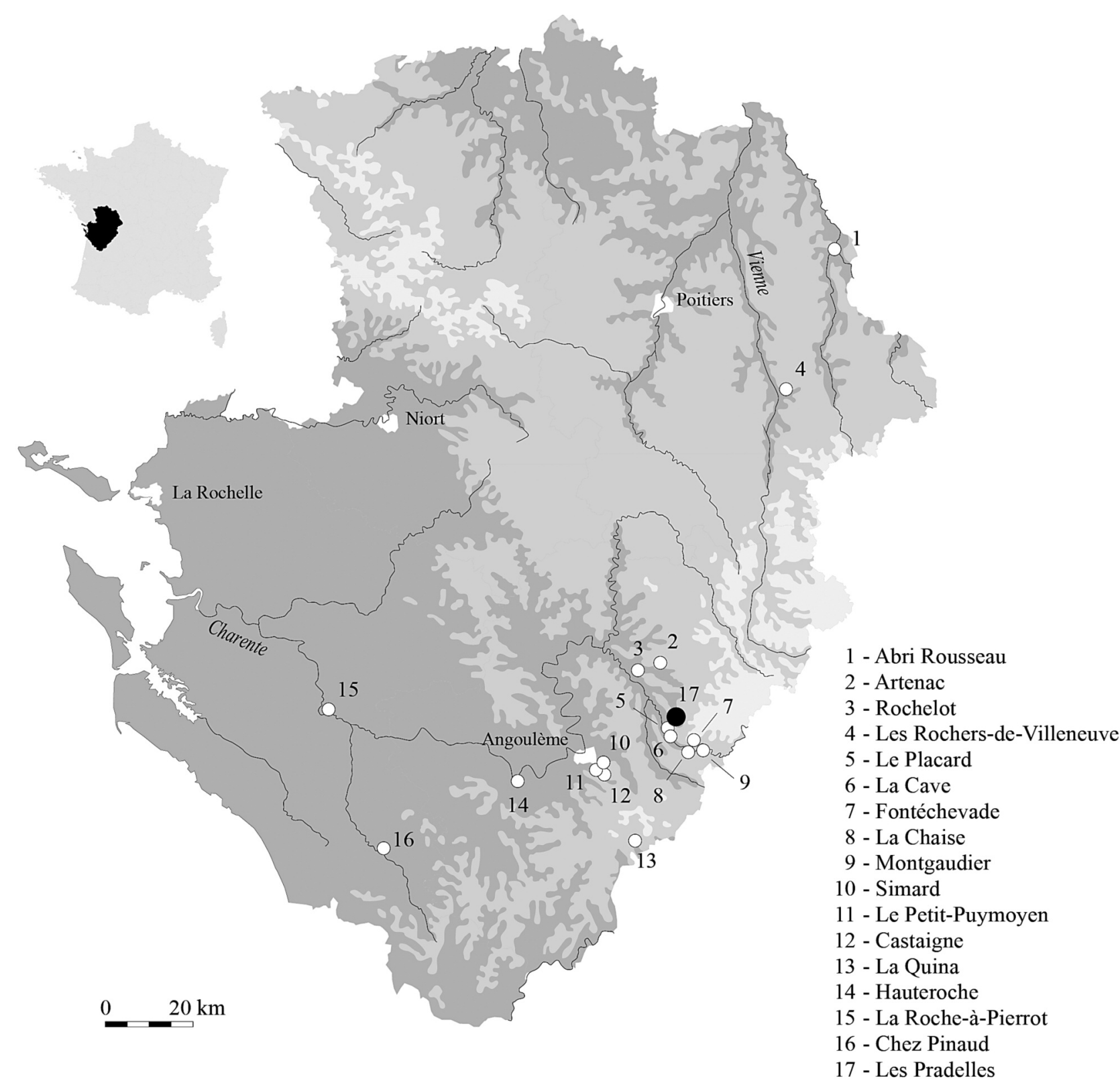

Figure 1 - Location (\# 17) of Marillac and others sites in the ancient Poitou-Charentes French Region where Neandertal lineage remains have been discovered are also shown.

Figure 1 - Localisation ( $\left.n^{\circ} 17\right)$ de Marillac et d'autres sites de l'ancienne région de Poitou-Charentes qui ont livré des restes humains appartenant à la lignée néandertalienne.

The existence of these teeth, with their ambiguous morphology modified in such a way as to make their recognition, as hominin, extremely difficult, has prompted the presentation of this report.

\section{2 - Site context}

The site has a complex geological and sedimentological history. Presently it is a large rectangular depression, some 12 meters long, 9 meters wide and about 3 to 9 meters deep representing the remains of a Bajocian limestone collapsed karstic cave. Figure 3 presents the eastern site locus from which the majority of hominin fossils have been recovered, including the two teeth presented in this article. At the base of the profile, sedimentological facies $2 a$ to $4 b$ (which are clast-supported limestone deposits associated to a clayey matrix; fig. 3) contain the most important archaeological remains, including lithics of the Quina Mousterian technocomplex (Meignen and Vandermeersch, 1986; Bourguignon, 1997). Reindeer largely dominate the associated ungulate 


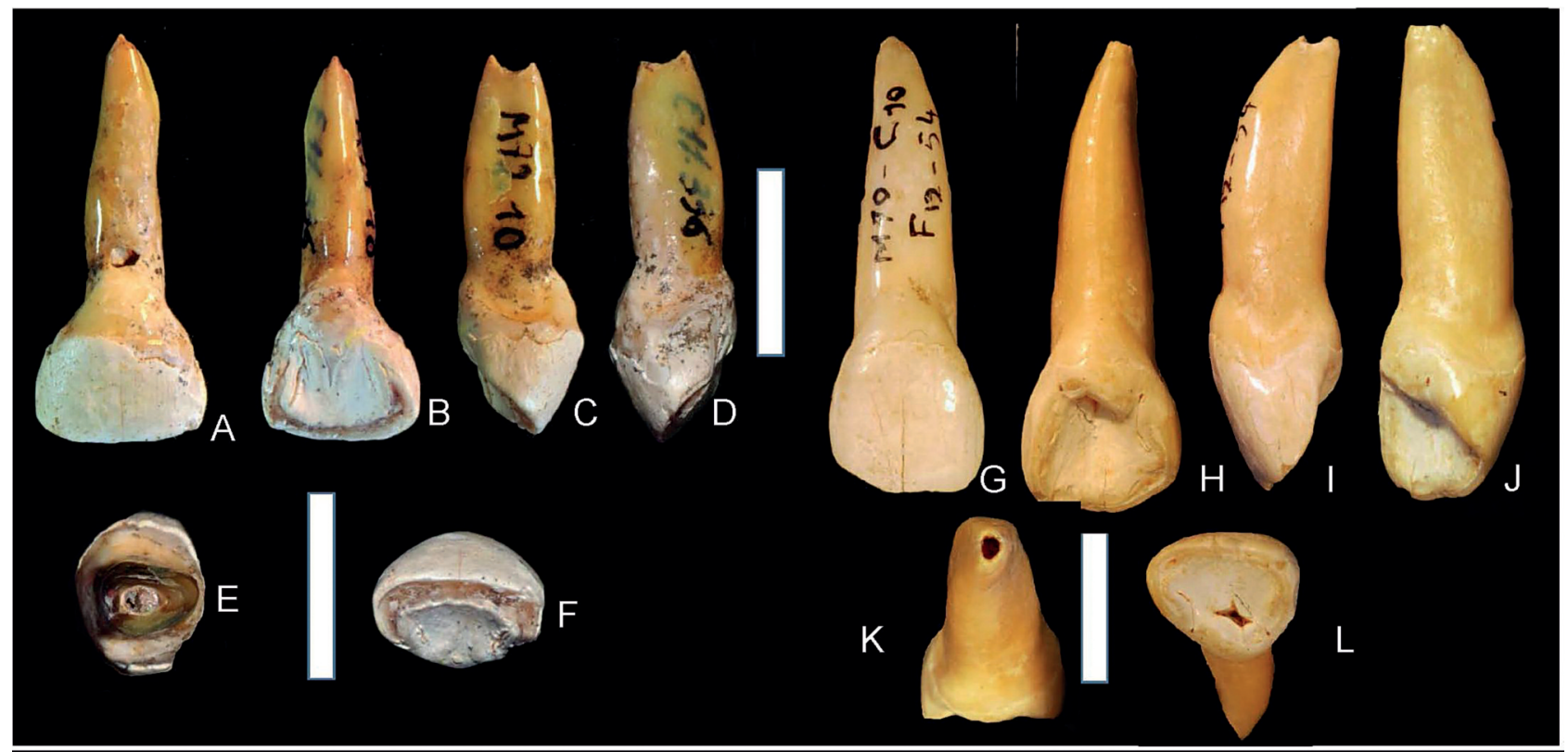

Figure 2 - The two permanent regurgitated Neandertal incisors. A to F: upper right central incisor (M72 C.10 E11 \# 336), G to L: upper right lateral incisor (M70 c.10 F12 \# 54). A and G: buccal view, B and H: lingual view, C and J: mesial view, D and l: distal view, E and $K$ : apical view, $F$ and $L$ : occlusal view. Scale $=10 \mathrm{~mm}$. Note that the layer 10 (c.10) defined by B. Vandermeersch is equivalent to a part of facies $2 a$ of the 2001-13 excavations.

Figure 2 - Les deux incisives permanentes néandertaliennes régurgitées. A à $F$ : incisive centrale supérieure droite (M72 c.10 E11 $n^{\circ}$ 336), $G$ à $L$ : incisive latérale supérieure droite (M70 c.10 F12 $\left.n^{\circ} 54\right)$. A et $G$ : vue vestibulaire, $B$ et $H:$ vue linguale, $C$ et $J:$ vue mésiale, $D$ et $I$ : vue distale, $E$ et $K:$ vue apicale, $F$ et $L:$ vue occlusale. Echelle $=10 \mathrm{~mm}$. Notez que la couche 10 (c.10) définie par B. Vandermeersch est équivalente à une partie du facies 2a des fouilles 2001-2013.

fauna (NISP close to $95 \%$ ). A small number of carnivore bones of cave hyena, cave lion, wolf and fox have also been recovered from these levels (Costamagno et al. 2005). Some complete coprolites, gnaw marks on herbivore bones as well as some regurgitated bone fragments, reindeer petrous bones and cervid or hyena teeth in the base of facies $2 a$ and facies $4 \mathrm{~b}$ document some active involvement of carnivores in either primary accumulation or in secondary scavenging related to hominin activities. In much of facies $2 \mathrm{a}$ and facies $2 \mathrm{~b}$, small pieces of coprolites and a few partially digested bone fragments (no more than 37 numbered fragments from a total sample of 3423 ; this does not include the numerous very small bone/ tooth fragments from this facies) also attest to the presence of carnivores, most probably cave hyena rather other Pleistocene carnivores (Mann et al. 2005).

The detailed chronological results of the site are presented in Frouin et al. (submitted this volume) which demonstrate that the age of the Neanderthal fossils is around 55 ka, and dates the Quina occupations between the end of Marine Isotope Stage (MIS) 4 and into the MIS 3 (see also Royer 2013; Royer et al. 2013; Frouin 2014).

\section{3 - Description of the two teeth}

(fig. $4 a$ and $4 b$ )

They are an upper permanent central incisor, perhaps right side (M72 C.10 E11 \# 336) and an upper permanent lateral right incisor (M70 c.10 F12 \# 54), both discovered in layer 10 (equivalent to a part of facies 2a). Both possess marked occlusal attrition, stage 4 for the central incisor and 3 for the lateral one following the analysis of dental attrition published by Murphy in Smith (1984). Given the differences in occlusal wear on the two teeth, and the observed differences in wear between incisors in any Neandertal jaw, it is not possible to state with certainty that they derive from the same individual. A detailed description of the morphological traits, crown and root characteristics and diameters of these teeth as well as micro CT-scans and 3D dental tissue proportions will be presented by Garralda et al. (in preparation).

These teeth present numerous unusual features (figure $4 a$ and $4 b$ ). Techniques such as scanning electronic microscopy and CT scanning provide a large corpus of useful information but the amassing of this data it is not the main aim of this article. Here the focus is essentially on their gross morphology and the external aspects of the enamel and dentine; the goal is to provide the essential macroscopic features to identify partially digested human teeth. The unusual features of the two Marillac incisors are: 1) The relative proportions between crown and root diameters, specifically for the central incisor, are not those of a permanent tooth. They are more appropriate in a deciduous tooth with an almost completely calcified root; 2) The roots of both teeth are very flat mesio-distally and bucco-lingually. This morphology is more accentuated on 


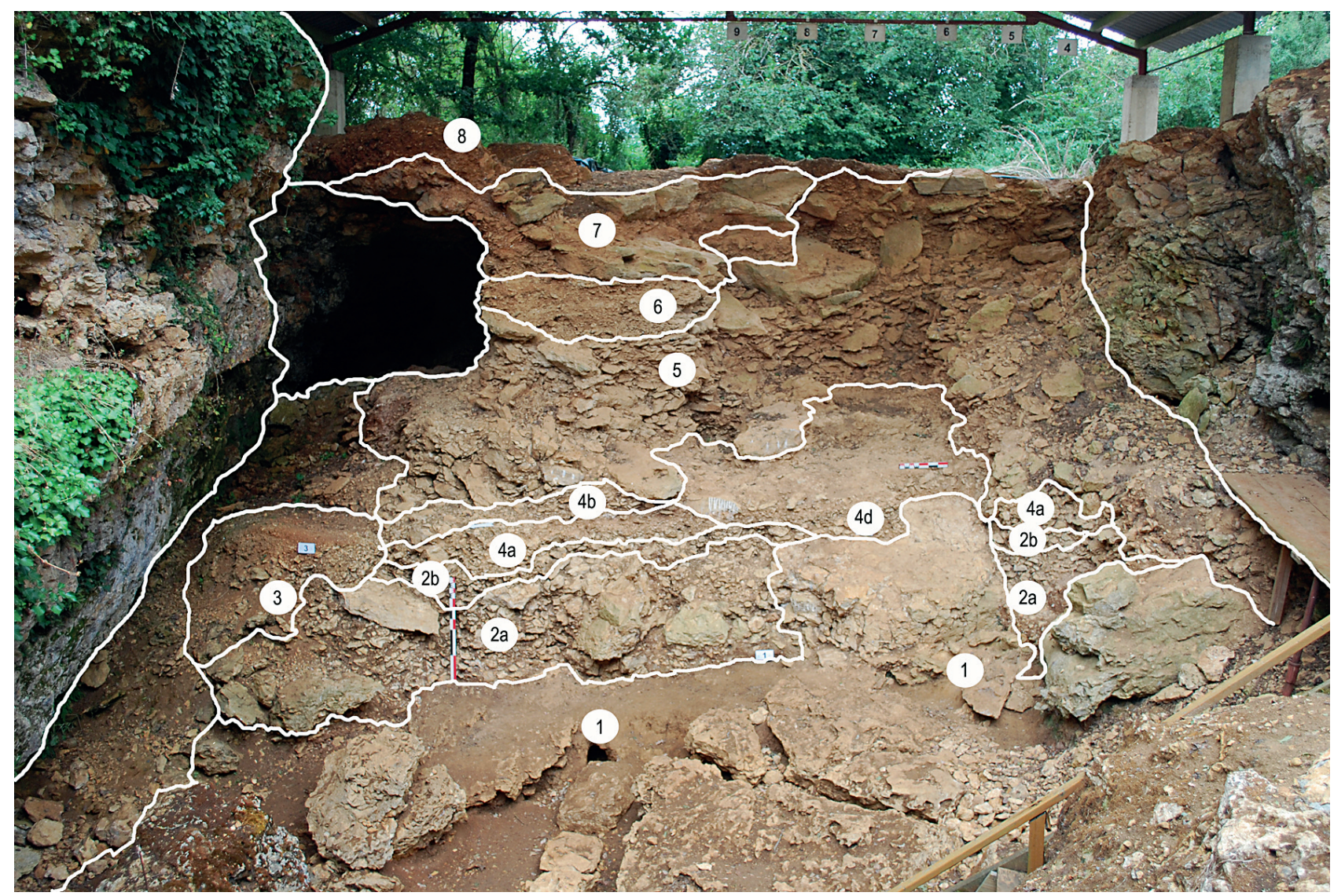

Figure 3 - Eastern locus of Marillac/Les Pradelles with the identified lithofacies related to 2001-2013 excavations. 1: silty endokarstic clays with large blocks embedded, sterile; 2a: clast-supported deposits associated to a clayey matrix, abundant archaeological material; 2b: clast supported deposits with voids partially filled in, abundant archaeological material; 3: recent sedimentation related to the present plateau topography, clast-supported deposits associated to sandy and clayey redeposited matrix, mixing of prehistorical and historical sediments, very rare archaeological material; 4a: clast-supported deposits associated to a clayey matrix, abundant archaeological material; 4b: compacted clast-supported deposits associated to a clayey matrix, less abundant archaeological material; 4d: cemented clast-supported deposits associated to a clayey matrix, abundant archaeological material; 5: clast supported deposits with voids partially filled in, rare archaeological material, carnivore occupations; 6: solifluxion layer, alternation of pebbly levels, clast-supported, and matrixsupported levels, very rare faunal remains; 7: slabs and clast supported deposits associated to an heterogeneous matrix, sterile; 8: recent soil with bioturbation.

Figure 3 - Locus est de Marillac/Les Pradelles avec les facies sédimentaires identifiés durant les fouilles 2001-2013. 1 : argiles limoneuses endokarstiques avec parfois quelques blocs de calcaire de taille variable, stérile; $2 a$ : cailloutis colmatés par une matrice argilo-limoneuse, matériel archéologique abondant ; $2 b$ : cailloutis peu ou non colmatés (vides entre les blocs), matériel archéologique abondant ; 3 : dépôt sédimentaire très récent relié à l'actuelle topographie, cailloutis colmatés inclus dans une matrice sablo-argileuse hétérogène : mélanges de sédiments anciens et récents, matériel archéologique très rare ; $4 a$ : fragments rocheux hétérométriques jointifs avec une matrice sablo-argileuse, couleur jaunâtre, matériel archéologique abondant; $4 b$ : fragments rocheux hétérométriques jointifs avec une matrice sablo-argileuse, couleur brune, matériel archéologique moins abondant ; $4 d$ : fragments rocheux hétérométriques jointifs et cimentés associés à une matrice très fine, matériel archéologique abondant ; 5 : éboulis hétérométriques à structure ouverte à semi-ouverte, matériel archéologique rare, repaire de carnivore; 6 : dépôts stratifiés, coulées de solifluxion avec alternance de niveaux de blocailles, de cailloutis et de sédiments plus fins, restes fauniques très rares ; $7:$ dalles calcaires et de cailloux très hétérométriques inclus dans une matrice sablo-argileuse hétérogène, stérile; 8 : Sol récent et bioturbé.

the central than on the lateral incisor and is unusual for a permanent tooth;

3) The two root apices are open and very large for teeth with such marked attrition. An almost completely calcified permanent (or deciduous) incisor does not possess an open apex of this size. Note that such a size is also inappropriate for a partially resorbed deciduous incisor root;
4) Atypical too are the polished root surfaces lacking cementum;

5) The dentine exposures on the occlusal surface of both teeth have a polished patina. In contrast, the borders of the enamel appears more irregular;

6) Finally and more intriguing, the apical limits of the enamel of both incisors (figure $4 \mathrm{a}$ and $4 \mathrm{~b}$ : open arrow) are not 


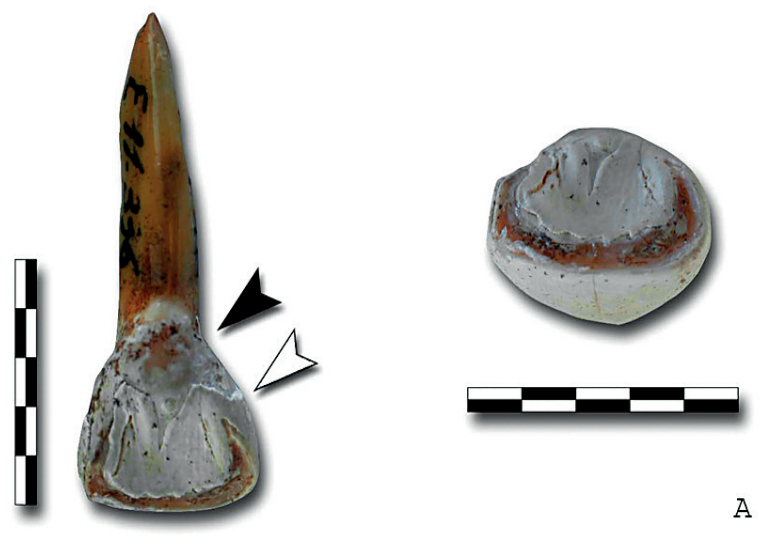

Figure 4a - Upper right central incisor (M72 c.10 E11 \# 336): lingual and occlusal views. Open arrow: apical limit of the enamel, solid arrow: anatomical cervix. Scale in millimeters, each gradation $=2 \mathrm{~mm}$.

Figure 4a - Incisive centrale supérieure droite (M72 c.10 E11 $\left.n^{\circ} 336\right)$ : vues linguale et occlusale. Flèche blanche : limite apicale de l'émail, flèche noire : limite anatomique du collet. Échelle en millimètres, chaque graduation $=2 \mathrm{~mm}$.

located at their normal positions, i.e. the anatomical cervix (fig. $4 \mathrm{a}$ and $4 \mathrm{~b}$ : solid arrow). They terminate well away from them. Note also that the central incisor possesses a very irregular cervical border, while the border on the lateral incisor, though smooth and regular, has an abnormal convexity.

Although this unusual suite of features is not present to the same degree of development/extension on the two incisors and does not have the same modifying impact on their normal morphology, their overall modifications are similar. This indicates they were subject to the same taphonomic processes.

Significant research has been undertaken to more fully understand the various modifications observed on the faunal and human remains from archaeological sites (i.e. Horwitz and Smith 1988; Fisher 1995; Brugal et al. 1997; Selvaggio 2001; Egeland et al. 2004; Domínguez-Rodrigo and Piqueras 2003). Taphonomic modifications include abrasion, weathering, the action of vegetation, animals and soil acidity (for example, Lyman 1994; Hedges and Millard 1995; Nicholson 1998; Nielsen-Marsh and Hedges 2000; Pickering et al. 2004; Fernández-Jalvo and Andrews 2016). Because the three hard dental tissues (enamel, dentin and cementum) composing a tooth are characterized by distinct compositions and structures (enamel is the most mineralized of the tissues, dentin and cementum less so; i.e. Hillson 2014), some of these processes would differentially act on a tooth.

\section{4 - Potential pathology}

A literature review (Hillson 1996, 2014; Piette and Goldberg 2001) failed to discover any pathological conditions that

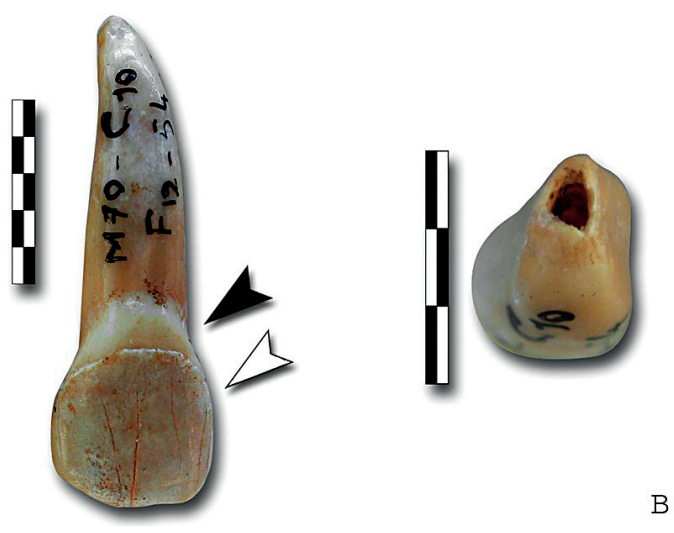

Figure 4b - Upper right lateral incisor (M70 c.10 F12 \# 54): buccal and apical views. Open arrow: apical limit of the enamel, solid arrow: anatomical cervix. Scale in millimeters, each gradation $=2 \mathrm{~mm}$.

Figure $4 b$ - Incisive latérale supérieure droite (M70 c.10 F12 $\left.n^{\circ} 54\right)$ : vues vestibulaire et apicale. Flèche blanche : limite apicale de l'émail, flèche noire : limite anatomique du collet. Échelle en millimètres, chaque graduation $=2 \mathrm{~mm}$.

could explain such unusual crown and root morphology on human permanent incisors or any other tooth type.

\section{5 - Soil acidity (fig. 5)}

Soil acidity is one possible agent that might produce modifications on teeth. Enamel is the most mineralized hard tissue in the body, with its mineral structure and crystallinity organized to resist to corrosive effects of dietary and digestive acids (Dawes 2003 ; Pasteris et al. 2008). However, to assess the possibility that soil acidity might have been responsible for the modifications observed on the Neandertal incisors, modern deciduous and permanent bovid isolated molars were placed in a $10 \%$ formic acid solution $(\mathrm{PH}=2.91)$. This obviously is not a precise measure of the soil acidity at Marillac, and while formic acid at this concentration is considered an irritant and not corrosive, it nevertheless represents a reasonable way to observe the reaction of the various parts of the teeth to the action of an acid. Figure 5 illustrates the teeth before immersion in the formic acid and after 22 hours in this acid solution. Note the decrease of the mesio-distal diameter of the crown: $5.8 \%$ for the deciduous tooth, $3.3 \%$ for the permanent molar as well as the more limited loss of tissue at the cervix: $0.74 \%$ for the deciduous tooth, $0.66 \%$ for the permanent molar.

The acid treatment produced obvious changes on the morphology of the teeth: the heavily mineralized enamel crowns have been markedly transformed by immersion in the formic acid solution while the root, composed of less mineralized dentine, shows little change. The acid worked primarily on the mineralized portion of the dental tissues. The reduction in the size of the crowns is greater than in the roots. These changes to root and crown sizes are exactly 

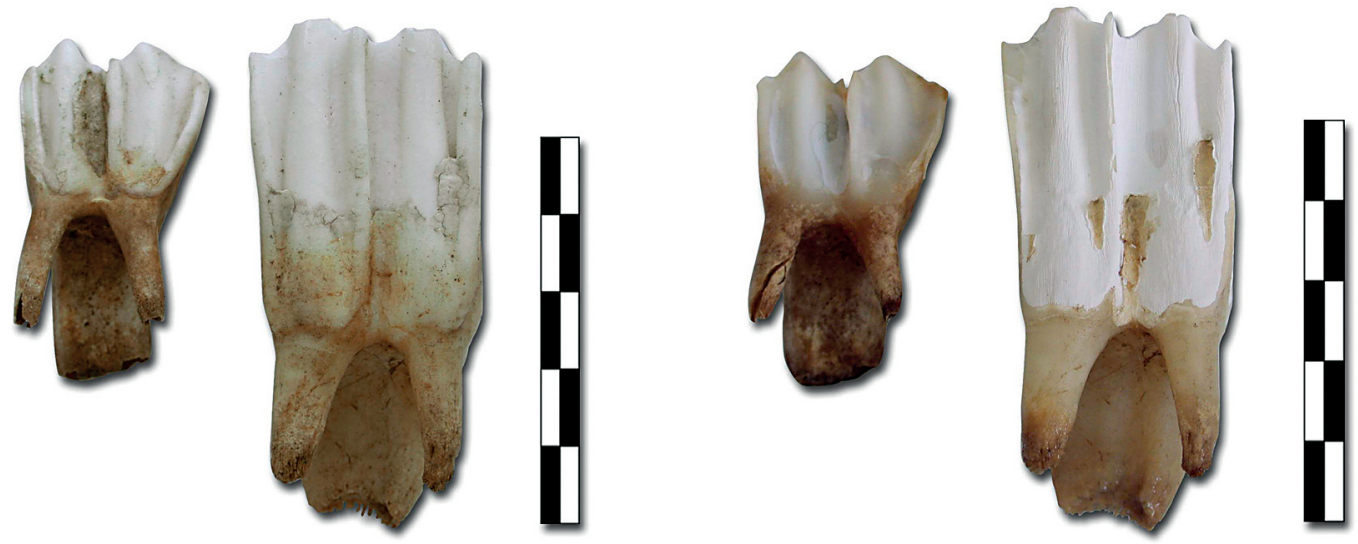

Figure 5 - Deciduous and permanent bovid molars (buccal view). Left, before acid immersion. Right, after 22 hours in a $10 \%$ solution of formic acid. Scale in centimeters, each gradation $=10 \mathrm{~mm}$.

Figure 5 - Molaires déciduale et permanente de bovidé (vue vestibulaire). À gauche, avant l'immersion dans l'acide. A droite, après 22 heures dans une solution à $10 \%$ d'acide formique. Échelle en centimètres, chaque graduation $=10 \mathrm{~mm}$.

opposite from the modifications observed on the Neandertal incisors from Marillac; that is to say, those teeth showed greater loss of root dentine tissue and less on the more heavily mineralized crown.

Many isolated faunal and human teeth are known from Marillac (and from many Upper Pleistocene sites from the south-west of France) and virtually all of them possess normal morphology. Thus, it is extremely unlikely that soil acidity, never very important within the high $\mathrm{pH}$ limestone karstic caves, could be the main factor that produced these unusual dental modifications.

\section{6 - Partial digestion by carnivores (fig. 6)}

Research (Sutcliffe 1970; Binford 1981; Andrews 1990, 1995; Cruz-Uribe 1991; d'Errico and Villa 1997; Dauphin et al. 2003; Pickering et al. 2004; Backwell et al. 2009; Camarós et al. 2017) provides evidence for another taphonomic process that results in modifications to hard tissues: the action of digestive enzymes and acids during consumption by a variety of animals including birds (eagles, vultures), reptiles (crocodiles) and mammalian carnivores (lion, wolf, hyena). The combination of digestive acids, enzymes and time (Denys et al. 1995) generally leads to the destruction to both mineral and organic components of the tooth (Fernández-Jalvo and Andrews 2016); the soft tissues (the organic material) will disappear first (with some variability; Pickering 2001).

To assess the potential that digestive processes might have on dental tissues, the two incisors were compared to a sample of partially digested faunal teeth directly associated with hyena occupations (i. e. Villa et al. 2004; Fourvel 2012; Fourvel et al. 2015) from the French Pleistocene sites of Les Plumettes (Airvaux 1987) and les Rochers-deVilleneuve (Beauval et al. 2005). The major modifications on these faunal teeth are a differential erosion of dentine and enamel, especially at the cervix, a reduction in the
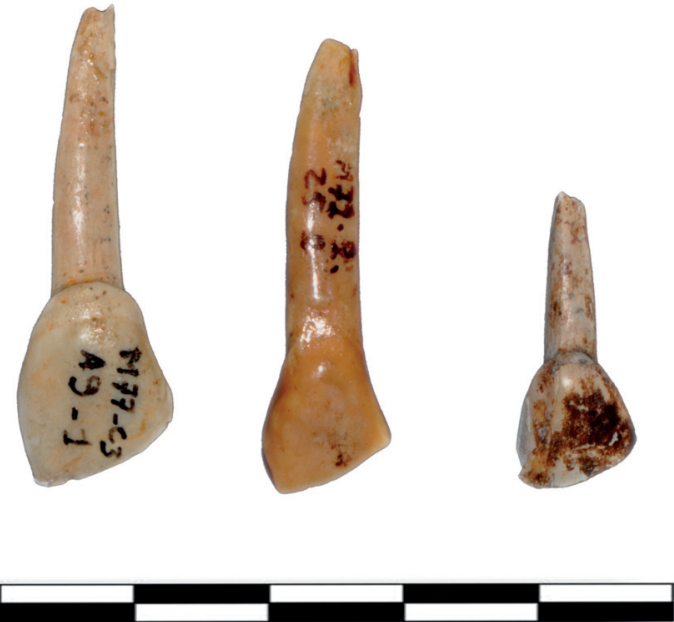

Figure 6 - Bovid regurgitated teeth from Marillac with similar or more pronounced modifications than the two Neandertal incisors. The difference between the anatomical cervix and the present one is very clear on the tooth on the left. For the three teeth, the root apices are largely opened. The tooth in the middle no longer possesses enamel and the dentine crown has been affected by the process. It explains why the asymmetry between the crown and the root breadth seems less pronounced. The tooth on the right presents the same degree of modifications as the left one but with more preserved enamel and a shorter root. It was probably not the same incisor number. All three teeth possess marked opening of the root apex. Scale in centimeters, Each gradation $=10 \mathrm{~mm}$

Figure 6 - Dents régurgitées de bovidés de Marillac avec des modifications similaires ou plus accentuées que les deux incisives néandertaliennes. Sur la dent à gauche, la différence entre collet anatomique et extension de l'émail est bien visible. La dent du milieu ne montre plus du tout d'émail et la dentine coronaire a aussi été affectée, ce qui diminue la dissymétrie couronne-collet. La dent de droite présente les mêmes caractéristiques que celle de gauche avec un émail mieux conservé mais une racine plus courte. Elle n'est probablement pas du même rang. Pour les trois dents, l'apex de la racine est largement ouvert. Échelle en centimètres, chaque graduation $=10 \mathrm{~mm}$. 
diameter and length of the root, and a significant widening of the root apex. This is the result of both digestive enzymes, like pepsin, which break down the collagen component of the less mineralized dentin and cementum and digestive acids which decalcify the mineral portion of both enamel and dentin.

It is clear from this examination of teeth from Pleistocene hyena dens that the morphological modifications produced by their partial digestion are the same as those observed on both Neandertal teeth from Marillac. Figure 6 illustrates three bovid incisors from Marillac with the same modifications, at different stages of the process, produced by carnivore partial digestion.

\section{7 - Discussion}

Archaeological analysis of the remains from facies $2 a$ and $2 \mathrm{~b}$ of Marillac strongly suggests that this site served repetitively over time as a hunting camp. Many reindeer carcasses, as well as those of several horses and bisons, were butchered and prepared for transport and storage to another location for consumption (Costamagno et al. 2006; Meignen et al. 2010).

There is also evidence at Marillac of human manipulation of dead Neandertals (Vandermeersch 1971, 1976a; Le Mort 1987, 1988; Garralda et al. 2005; Garralda 2008; Mussini 2011). More than $35 \%$ of the Marillac Neandertal cranial and infracranial pieces (both mature and juvenile individuals) present unquestionable cut-marks (indicative of scoring with a stone tool), percussion pits and incipient fracture lines. Internal vault releases (White 1992) are also identifiable on different skull fragments. These observations document butchery practices on these humans. The presence of butchered Neandertal bones may indicate cannibalism at Marillac (Maureille et al. 2010; Mussini 2011), or some other cultural practice that did not involve consumption (Garralda and Vandermeersch 2000; Garralda et al. 2005; Garralda 2008; Pettitt 2011).

The most parsimonious explanation to account for the partial digestion of human teeth is that faunal elements left after butchery, as well as hominin remains, were abandoned and subsequently scavenged by carnivores.

Since the initial identification of partially digested incisors at Marillac (Costamagno et al. 2003), five other teeth at the same site, a left lower second permanent molar (M71 c.9/10), a first left premolar (M72 c.11 I10 \# 22), a first left lower deciduous molar (M73 c.10 E10), a germ of a lateral left upper incisor (M75 c.11 H9 \# 3) have also been identified. Descriptions, as well as $3 D$ and virtual reconstructions of the Marillac teeth are being prepared for publication (Garralda et al., in preparation).

\section{8 - Conclusion}

The examination of some difficult to interpret morphological features on two isolated teeth from the Marillac site that had been previously identified as those of a bovid or a cervid deciduous teeth has resulted in their identification as partially digested Neandertal maxillary incisors.
This contribution gives also macroscopic key features to identify such peculiar taphonomic modifications on isolated human teeth and which could help to find, within faunal collection samples, new human fossils. The description of the complete set of regurgitated Neandertal teeth from Marillac will perhaps also help to discuss the impact of the partial digestion by carnivores of partial human maxillas or mandibles.

An implication of this research is that more attention ought to be directed to faunal samples from sites where large predators may have been involved in their accumulation. Hyena dens were a frequent feature in Western Europe at the end of Mousterian times (Discamps 2011; Discamps 2014). For some of them, for example Rochelot (Tournepiche and Couture 1999), Les Rochers-deVilleneuve (Beauval et al. 2005), partially gnawed hominin bones (humerus, femur) and isolated teeth have been discovered. It is likely that additional examples of regurgitated hominin teeth are present in the faunal collections from similar sites, but may not have been considered human, identified instead as deciduous teeth of a medium or large mammal. Bovid and cervid anterior teeth with notable occlusal attrition but with an open (and large) root apex can be more carefully examined for a discrepancy between the crown's apical border and the tooth cervix, the partial absence of enamel, an abnormal enamel thickness or the asymmetry between the breadth of the crown and the root. A polished luster over the entire tooth and a relative lack of cementum are also useful signs.

A literature review has resulted in the discovery of similar modifications on hominin posterior teeth from the Upper Pleistocene sites of Grotte du Bison (Yonne, figure 3 in Tillier et al. 2013a) and Grotte des Hyènes at Arcy-sur-Cure (Yonne, Auy H D6 Iva, unpublished, pers. obs.). Moreover, a left deciduous central incisor of Paranthropus robustus (SWT3-2433) from Member 3 of Swartkrans (South Africa; figure 2 in Pickering et al. 2016) also appears to possess the same modifications. Note that the authors of these articles provide crown diameters of the teeth, but apparently do not take into consideration the possible reduction of their crown dimensions. However, such a taphonomic process has a real influence on the metrical dimensions of the crown and root. This was emphasized by Tillier et al. (2013b) for an upper permanent third molar which may very well have been partially digested. It is worth noting that all these teeth were identified as hominin, indicating it is essentially incisors and canines where carnivore digestive processes have resulted in changes in crown and root morphology that make recognition as hominin difficult and confusing.

\section{Acknowledgments}

We thank the Ministère de la Culture of France, the Service Régional de l'Archéologie (DRAC Poitou-Charentes), the Conseil Général de la Charente, the Conseil Municipal de Marillac-le-Franc and its residents, Princeton University, the CNRS, University of Bordeaux, UMR5199 PACEA, P. Guyomarc'h, E. Schostmans, D. Cochard, E. Discamps, B. Gravina for discussions and bibliographic help, F. Sémah and D. Grimaud-Hervé for access to the Arcysur-Cure material curated at the Institut de Paléontologie 
humaine (Paris). This work has been supported by the Research Program of the Aquitaine Region: Transitions, d'une société à l'autre processus d'adaptation et de peuplements, convention $\mathrm{n}^{\circ}$ 20051403003AB and by the Scientific Project: NéMo of the LabEx Sciences archéologiques de Bordeaux, support provided by the ANR - $\mathrm{n}^{\circ}$ ANR-10-LABX-52 / LaScArBx, the Research Program of the Nouvelle Aquitaine Region: Neanderthalenses Aquitanensis: Teritoires, Chronologie, Humanité convention $\mathrm{n}^{\circ}$ 2016-1R40204-00007349-00007350. We also acknowledge the editorial board of Paleo and the reviewers for their very helpful comments that improved the manuscript.

\section{Bibliography}

AIRVAUX J. 1987 - Le site des «Plumettes» à Lussac-lesChâteaux (Vienne). In: Actes du $111^{\circ}$ Congrès National des Sociétés Savantes, Pré- et Proto- histoire; Préhistoires de Poitou-Charentes. Problèmes actuels. Éds. Du CTHS, Paris, pp. 194-202.

ANDREWS P. 1990 - Owls, caves and fossils. The Natural History Museum, London.

ANDREWS P. 1995 - Experiments in taphonomy. J. Archaeol. Sci., 22, 147-153.

BACKWELL L., PICKERING R., BROTHWELL D., BERGER L., WITCOMB M., MARTILL D., PENKMAN K., WILSON A. 2009 - Probable human hair found in a fossil hyaena coprolite from Gladysvale cave, South Africa. J. Archaeol. Sci., 36, 1269-1276.

BEAUVAL C., MAUREILLE $\quad$ B., LACRAMPECUYAUBÈRE F., SERRE D., PERESSINOTTO D., BORDES J.-G., COCHARD D., COUCHOUD I., DUBRASQUET D., LAROULANDIE V., LENOBLE A., MALLYE J.-B., PASTY S., PRIMAULT J., ROHLAND N., PÄÄBO S., TRINKAUS E. 2005 - A late Neandertal femur from Les Rochers-de-Villeneuve, France. Proc. Natl. Acad. Sc. USA, 102, 7085-7090.

BINFORD L. 1981 - Bones: Ancient Men and Modern Myths. Academic Press, New-York.

BOURGUIGNON L. 1997 - Le Moustérien de type Quina: nouvelle définition d'une entité technique. Thèse Université Paris 10 Nanterre.

BRUGAL J.-P., FOSSE P., GUADELLI J.-L. 1997 Comparative study of bone assemblages made by recent and Pleistocene Hyenids. In : Hannus L. A., Rossum L. and Winham R. P. (coord.), Proceedings of the 1993 bone modification conference, Hot Springs, South Dakota. The eighth meeting of working group 1 on bone modification. Occasional Publication $\mathrm{n}^{\circ} 1$, Archeology Laboratory, Augustana College, South Dakota: Sioux Falls, pp.158-187.

BUCKLEY M., COLLINS M.J. 2011 - Collagen survival and its use for species identification in Holocene-lower Pleistocene bone fragments from British archaeological and paleontological sites. Antiqua, 1, e1.
CAMARÓS E., CUETO M., ROSELL J., DÍEZ J. C., BLASCO R., DUHIG C., DARLAS A., HARVATI K., JORDÁ J., MONTES L., VILLAVERDE V., RIVALS F. 2017 - Hunted or scavenged Neanderthals? Taphonomic approach to hominin fossils with carnivore damage. Int. J. Osteoarcheol., doi: 10.1002/oa.2584

COSTAMAGNO S., BEAUVAL C., VANDERMEERSCH B., MANN A.E. MAUREILLE B. 2003 - Middle Paleolithic teeth digested by carnivores (Les Pradelles, Marillac-le-Franc, France). Palaeoanthropological meeting, Phoenix 2003, www.paleoanthro.org/abst2003.htm, pp. 9-10.

COSTAMAGNO S., BEAUVAL C., LANGE-BADRÉ B., VANDERMEERSCH B., MANN, A.E., MAUREILLE B. 2005 - Homme ou carnivores ? Protocole d'étude d'ensembles osseux mixtes: l'exemple du gisement moustérien des Pradelles (Marillac-le-Franc, Charente). Archaeofauna, 14, 43-68.

COSTAMAGNO S., MEIGNEN L., BEAUVAL C., VANDERMEERSCH B., MAUREILLE B. 2006 - Les Pradelles (Marillac-le-Franc, France): A mousterian reindeer hunting camp? J. Anthrop. Arch., 25, 466-484.

CRUZ-URIBE K. 1991 - Distinguishing hyena from hominid bone accumulations. J. Field Archaeol., 18, 467-486.

DAUPHIN Y., ANDREWS P., DENYS C., FERNANDEZJALVO Y., WILLIAMS T. 2003 - Structural and chemical bone modifications in a modern owl pellet assemblage from Olduvai Gorge (Tanzania). J. Taphonomy, 1, 209-232.

DAVID P. 1934 - Communication en séance «Ossements fossiles découverts récemment dans un abri-repaire inédit». Bull. Mém. Soc. Arch. Hist. Charente, année 1933, 37-38.

DAVID P. 1935 - Les fouilles de l'abri-repaire de Marillac, près La Rochefoucauld. Bull. Mém. Soc. Arch. Hist. Charente, année 1934, 89-90.

DAWES C. 2003 - What is the critical pH and why does a tooth dissolve in acid? Journal of the Canadian Dental Association, 69, 722-724.

D'ERRICO F., VILLA P. 1997 - Holes and grooves: the contribution of microscopy and taphonomy to the problem of art origins. J. Hum. Evol., 33, 1-31.

DENYS C., FERNANDEZ-JALVO Y., DAUPHIN Y. 1995 Experimental taphonomy: preliminary results of the digestion of micromammal bones in the laboratory. $C . R$. Acad. Sc., sér. 2., Sc. terre et planètes, 321, 803-809.

DISCAMPS E. 2011a (unpublished) - Hommes et hyène face aux recompositions des communautés d'Ongulés (MIS 5-3) : éléments pour un cadre paléoécologique des sociétés du Paléolithique moyen et supérieur ancien d'Europe de l'Ouest. Thèse de l'Université Bordeaux 1, École doctorale Sciences et environnements, spécialité préhistoire et géologie du quaternaire, $\mathrm{n}^{\circ}$ ordre 4440 . 
DISCAMPS E. 2014 - Ungulate biomass fluctuations endured by Middle and Early Upper Paleolithic societies (SW France, MIS 5-3): the contributions of modern analogs and cave hyena paleodemography. Quaternary International, 337: 64-79.

DOMÍNGUEZ-RODRIGO M., PIQUERAS A. 2003 - The use of tooth pits to identify carnivore taxa in tooth-marked archaeofaunas and their relevance to reconstruct hominid carcass processing behaviours. J. Archaeol. Sci., 30, 1385-1391.

EGELAND C.P., PICKERING T.R., DOMÍNGUEZRODRIGO M., BRAIN C.K. 2004 - Disentangling Early Stone Age palimpsests: determining the functional independence of hominid- and carnivore-derived portions of archaeofaunas. J. Hum. Evol., 47, 343-357.

FERNÁNDEZ-JALVO Y., ANDREWS P. 2016 - Atlas of taphonomic identificiations. Springer: London.

FISHER J.W. 1995 - Bone surface modifications in zooarchaeology. J. Archaeol. Method and Theory, 2, 7-68.

FOURVEL J.-B. 2012 (unpublished) - Hyénidés modernes et fossiles d'Europe et d'Afrique. Thèse de l'Université de Toulouse le Mirail, école doctorale Temps, espaces, sociétés et cultures.

FOURVEL J.-B., FOSSE P., AVERY G. 2015 - Spotted, striped or brown? Taphonomic studies at dens of extant hyaenas in eastern and southern Africa. Quat. Int., 369, 38-50.

FROUIN M. 2014 (unpublished) - Les Feldspaths comme support pour la datation par luminescence de gisements archéologiques et de séquences quaternaires d'Aquitaine. Thèse Univ. de Bordeaux Montaigne.

FROUIN M., LAHAYE C., MERCIER N., GUIBERT P., COUCHOUD I., TEXIER J.-P., ROYER A., COSTAMAGNO S., BEAUVAL C., BOURGUIGNON L., MEIGNEN L., BORDES J.G., SEGUIN G., BOCHERENS H., LACRAMPE-CUYAUBÈRE F., GRÜN R., GARRALDA M. D., VANDERMEERSCH B., MANN A. E., MAUREILLE B., (submitted this volume). Les Pradelles (Marillac-le-Franc, Charente) : chronologie d'un site moustérien de type Quina. Paleo, 28.

GARRALDA M.D. 2008 - Les Néandertaliens : d'autres gestes envers les défunts. In: VANDERMEERSCH B., CLEYET-MERLE J.-J., JAUBERT J., MAUREILLE B., TURQ A. (Eds.), Première humanité, gestes funéraires des Néandertaliens. Paris: Réunion des Musées Nationaux, p. $42-51$.

GARRALDA M.D., VANDERMEERSCH B. 2000 - Les Néandertaliens de Combe-Grenal (Domme, France). Paleo, 12, 213-259.

GARRALDA M.D., GIACOBINI G., VANDERMEERSCH B. 2005 - Cut marks on the Combe-Grenal and Marillac Neandertals. A SEM analysis. Anthropologie, 43, 251-271.
GARRALDA M.D., MAUREILLE B., VANDERMEERSCH B. 2014a - Hyperostosis frontalis interna in a Neandertal from Marillac (Charente, France). J. Hum. Evol., 67, 76-84.

GARRALDA M.D., MAUREILLE B., VANDERMEERSCH B. 2014b - Neanderthal infant and adult infracranial remains from Marillac (Charente, France). Am. J. Phys. Anthrop., 155, 99-113.

GARRALDA M.D., MAUREILLE B., LE CABEC A., OXILIA G., BENAZZI S., SKINNER M., HUBLIN J.-J., VANDERMEERSCH B. (in preparation).The Neanderthal teeth from Marillac: a morphometric and comparative study. J. Hum. Evol.

HEDGES R.E.M., MILLARD A.R. 1995 - Bones and groundwater: towards the modelling of diagenetic processes. J. Archaeol. Sci., 22, 155-164.

HILLSON S. 1996 - Dental Anthropology. Cambridge Univ. Press.

HILLSON S. 2014 - Tooth development in Human Evolution and Bioarchaeology. Cambridge Univ. Press.

HORWITZ L.K., SMITH P. 1988 - The effects of striped hyaena activity on human remains. J. Archaeol. Sc., 15, 471-481.

LE MORT F. 1987 - Incisions volontaires sur un arrièrecrâne de Néandertalien de Marillac (Charente). In: Actes du $111^{\circ}$ Congrès National des Sociétés Savantes, Pré- et Proto-histoire ; Préhistoires de Poitou-Charentes. Problèmes actuels. Éds. du CTHS, Paris, pp. 151-156.

LE MORT F. 1988 - Le décharnement du cadavre chez les Néandertaliens: quelques exemples. In : Bar-Yosef O. (ed), La pensée. L'Homme de Néandertal, vol. 5. Liège, ERAUL 32, pp. 43-55.

LYMAN R.L. 1994 - Vertebrate Taphonomy. Cambridge University Press, Cambridge.

MANN A.E., MAUREILLE B., VANDERMEERCH B. 2002 Les nouveaux restes humains des Pradelles (commune de Marillac-le-Franc, Charente). $1828^{\circ}$ réunion scientifique de la Soc. Anthrop. Paris. Bull. Mém. Soc. Anthrop. Paris, nouv. sér., 14, 217-218.

MANN A.E., BEAUVAL C., COSTAMAGNO S., BORDES J.-G., BOURGUIGNON L., COUCHOUD I., LACRAMPE F., LAROULANDIE V., MARQUET J.-CL., MEIGNEN L., TEXIER J.-P., VANDERMEERSCH B., MAUREILLE B. 2005 - Carnivore and Neandertal interactions at the Les Pradelles Site (Charente, Southwest France). Abstracts of the 2005 Palaeoanthropology society meeting (5-6 April 2005), Paleoanthropology AR University of Pensylvania Press, A28.

MAUREILLE B., MANN A.E., BEAUVAL C., BORDES J.-G., BOURGUIGNON L., COSTAMAGNO S., COUCHOUD I., LACRAMPE-CUYAUBĖRE F., LAROULANDIE V., MARQUET J.-C., MEIGNEN L., 
TEXIER J.-P., VANDERMEERSCH B. 2004a - Le gisement moustérien des Pradelles (Marillac-le-Franc, Charente): passé, présent, futur. In: Evin, J. (Ed.), Un Siècle de Construction du Discours Scientifique en Préhistoire, Congrès du Centenaire de la S.P.F., Avignon 2004, vol. III. Société Préhistorique Française, Paris, pp. 249-261.

MAUREILLE B., MANN A.E., VANDERMEERSCH B. 2004b - Newly discovered Neandertal remains from the Les Pradelles site (Marillac-le-Franc, South-West France). 73th annual meeting of the Am. Assoc. of Phys. Anthropologists, Tampa (Florida). Am. J. Phys. Anthrop., suppl. 73, 144.

MAUREILLE B., MANN A.E., BEAUVAL C., BORDES J.-G., BOURGUIGNON L., COSTAMAGNO S., COUCHOUD I., FAUQUIGNON J., GARRALDA M.D., GEIGL E.-M., GRÜN R., GUIBERT P., LACRAMPECUYAUBĖRE F., LAROULANDIE V., MARQUET. J.-Cl., MEIGNEN L., MUSSINI C., RENDU W., ROYER A., SEGUIN G., TEXIER J.-P. 2010 - Les Pradelles à Marillacle-Franc (Charente). Fouilles 2001-2007: nouveaux résultats et synthèse. In : Buisson-Catil, J., Primault, J., (Eds.), Préhistoire entre Vienne et Charente. Hommes et sociétés du Paléolithique. Association des publications chauvinoises, Mém. XXXVIII. Chauvigny, APC, pp. 145-162.

MEIGNEN L., VANDERMEERSCH B. 1986 - Le gisement moustérien de Marillac (Charente) couches 9 et 10. Caractéristiques des outillages. Économie des matières premières. In: Préhistoire de Poitou-Charentes. Problèmes Actuels. Actes du Congrès des Sociétés Savantes. Éditions du CTHS, Paris, pp. 135-144

MEIGNEN L., COSTAMAGNO S., BOURGUIGNON L., BEAUVAL C., MAUREILLE B. 2010 - Approche interdisciplinaire d'une halte de chasse au Paléolithique moyen. In: Buisson-Catil J., Primault J., (Eds.), Préhistoire entre Vienne et Charente. Hommes et sociétés du Paléolithique. Association des publications chauvinoises, Mém. XXXVIII. Chauvigny, APC, pp. 163-166.

MUSSINI C. 2011 (unpublished) - Les restes humains moustériens des Pradelles (Marillac-le-Franc, Charente, France). Étude morphométrique et réflexions sur un aspect comportemental des Néandertaliens. Thèse de doctorat, Université Bordeaux 1.

MUSSINI C., MANN A.E., GARRALDA M.D., MAUREILLE B. 2011 - Sur un occipital néandertalien des Pradelles (Marillac-le-Franc, Charente): étude morphométrique préliminaire. C R Palevol, 10, 589-595.

MUSSINI C., CRÈVECOEUR I., GARRALDA M.D., MANN A., MAUREILLE B. 2012 - A new Neandertal femoral diaphysis from Les Pradelles (Marillac-le-Franc, Charente, France). Periodicum Biologorum, 114, 117-123.

NICHOLSON R.A. 1998 - Bone degradation in a compost heap. J. Archaeol. Sci., 25, 393-403.
NIELSEN-MARSH C.M., HEDGES R.E.M. 2000 - Patterns of diagenesis in bone I: the effects of site environments. J. Archaeol. Sci., 27, 1139-1150.

PASTERIS J. D., WOPENKA B., VALSAMI-JONES E. 2008 - Bone and tooth mineralization: Why apatite? Elements, 4, 97-104.

PETTITT P. 2011 - The Palaeolithic Origins of Human Burial. New York: Routledge, p. 307.

PICKERING T.R. 2001 - Carnivore voiding: a taphonomic process with the potential for the deposition of forensic evidence. J. For. Sc., 46, 406-411.

PICKERING T.R., DOMÍNGUEZ-RODRIGO M., EGELAND C. P., BRAIN C. K. 2004 - Beyond leopards: tooth marks and the contribution of multiple carnivore taxa to the accumulation of the Swartkrans Member 3 fossil assemblage. J. Hum. Evol., 46, 595-604.

PICKERING T.R., HEATON J.L., SUTTON M.B., CLARKE R.J., KUMAN K., HUTTON SENJEM J., BRAIN C.K. 2016 New early Pleistocene hominin teeth from the Swartkrans Formation, South Africa. J. Hum. Evol., 100, 1-15.

PIETTE E., GOLDBERG M. (Eds.) 2001 - La dent normale et pathologique. Bruxelles, De Boeck University.

PIVETEAU J. 1951 - Images des mondes disparus. Paris, Masson, pp. 150-151.

PIVETEAU J. 1957 - Marillac. In : Traité de Paléontologie, vol. VII. Paris, Masson et Cie, pp. 473-474.

ROYER A. 2013 - Étude paléoenvironnementale et paléoclimatique du Pléistocène supérieur du Sud-Ouest de la France, à partir d'analyses comparées d'associations fauniques et de biogéochimies effectuées sur les micromammifères. Thèse de doctorat, École Pratique des Hautes Études.

ROYER A., LÉCUYER CH., MONTUIRE S., ESCARGUEL G., FOUREL FR., MANN A.E., MAUREILLE B. 2013 - Late Pleistocene (MIS 3-4) climate inferred from micromammal communities and $\delta^{18} \mathrm{O}$ of rodents from Les Pradelles, France. Quaternary Research, 80, 113-124.

SELVAGGIO M. 2001 - Identifying the involvement of multiple carnivore taxa with archaeological bone assemblages. J. Archaeol. Sci., 28, 465-470.

SMITH B. H. 1984 - Patterns of molar wear in huntergatherers and agriculturalists. American Journal of Physical Anthropology, 51, 213-217.

SUTCLIFFE A.J. 1970 - Spotted hyena: crusher, gnawer, digester and collector of bones. Nature, 227, 1110-1113.

TILLIER A.-M., HARDY M., DAVID F., GIRARD M., D'IATCHENKO V. 2013a - A propos de deux molaires déciduales inférieures provenant des niveaux moustériens de la Grotte du Bison (Arcy-sur-Cure, Yonne, France): un 
exemple de lésion cervicale inédite chez un enfant néanderthalien. Paleo, 24, 271-278.

TILLIER A.-M., SANSILBANO-COLLILIEUX M., DAVID F., ENLOE J. G., GIRARD M., HARDY M., D'IATCHENKO V., ROBLIN-JOUVE A., TOLMIE C. 2013b - Les vestiges néandertaliens provenant des niveaux moustériens I et $\mathrm{J}$ de la Grotte du Bison à Arcy-sur-Cure (Yonne) : bilan actuel. Bulletins et Mémoires de la Société d'Anthropologie de Paris, 25, 39-54.

TOURNEPICHE J.-F., COUTURE C. 1999 - The hyena den of Rochelot cave (Charente, France). In : The role of early humans in the accumulation of European Lower and Middle Palaeolithic bone assemblages. Mon. Röm.-Germ. Zentralmuseums, 42. Mainz, pp. 89-101.

VANDERMEERSCH B. 1965 - Position stratigraphique et chronologie relative des restes humains du Paléolithique moyen du Sud-Ouest de la France. Ann. Paléont., 51, 69-129.

VANDERMEERSCH B. 1971 - Marillac. In: Oakley KP, Campbell BG, Molleson T, (Eds.). Catalogue of Fossil Hominids, part II: Europe. London: Trustees of the B.M. (N.H.). pp 138-139.

VANDERMEERSCH B. 1976a - Les Néandertaliens en Charente. In: La Préhistoire Française, Vol. I, 1, Paris, Eds. CNRS, pp. 584-587.
VANDERMEERSCH B. 1976b - Marillac. Gallia Préhistoire, 19, 431-433.

VAN DOOR N.L., HOLLUND H., COLLINS M.J. 2011 - A novel and non-destructive approach for ZooMS analysis: ammonium bicarbonate buffer extraction. Archaeol Anthropol. Sci., 3, 281-289.

VILLA P., CASTEL J.C., BEAUVAL C., BOURDILLAT V., GOLDBERG P. 2004 - Human and carnivore sites in the European Middle and Upper Paleolithic: similarities and differences in bone modification and fragmentation. Revue de Paléobiologie, 23, 705-730.

WELKER F., HAJDINJAK,M., TALAMO S., JAOUEN K., DANNEMANN M., DAVID F., JULIEN M., MEYER M., KELSO J., BARNES I., BRACE S., KAMMINGA P., FISCHER R., KESSLER B.M., STEWART J.R., PÄÄBO S., COLLINS M.J., HUBLIN J.-J. 2016 - Palaeoproteomic evidence identifies archaic hominins associated with the Châtelperronian at the Grotte du Renne. Proc. Natl. Acad. Sc. USA, 113, 11162-11167.

WHITE T.D. 1992 - Prehistoric cannibalism at Mancos 5MTUMR-2346. Princeton Univ. Press, Princeton, NJ. 